\title{
Article
}

\section{Bicarbonate and Alkyl Carbonate Radicals: Their Structural Integrity and Reactions with Lipid Components}

Michael Buehl, Peter DaBell, David W. Manley, Rory P. McCaughan, and John C. Walton

J. Am. Chem. Soc., Just Accepted Manuscript • DOI: 10.1021/jacs.5b10693 • Publication Date (Web): 01 Dec 2015

Downloaded from http://pubs.acs.org on December 2, 2015

\section{Just Accepted}

"Just Accepted" manuscripts have been peer-reviewed and accepted for publication. They are posted online prior to technical editing, formatting for publication and author proofing. The American Chemical Society provides "Just Accepted" as a free service to the research community to expedite the dissemination of scientific material as soon as possible after acceptance. "Just Accepted" manuscripts appear in full in PDF format accompanied by an HTML abstract. "Just Accepted" manuscripts have been fully peer reviewed, but should not be considered the official version of record. They are accessible to all readers and citable by the Digital Object Identifier (DOI®). "Just Accepted" is an optional service offered to authors. Therefore, the "Just Accepted" Web site may not include all articles that will be published in the journal. After a manuscript is technically edited and formatted, it will be removed from the "Just Accepted" Web site and published as an ASAP article. Note that technical editing may introduce minor changes to the manuscript text and/or graphics which could affect content, and all legal disclaimers and ethical guidelines that apply to the journal pertain. ACS cannot be held responsible for errors or consequences arising from the use of information contained in these "Just Accepted" manuscripts. 


\section{INTRODUCTION}

Carbonic acid is a weak, diprotic acid formed upon dissolution of carbon dioxide in water. While its acid/base equilibria are well understood, its radical chemistry is not. Deprotonations produce the bicarbonate anion $\mathrm{HCO}_{3}{ }^{-}\left(p K_{\mathrm{a}}=6.38\right)$ and then carbonate dianion $\mathrm{CO}_{3}{ }^{2-}\left(p K_{a}=10.25\right)$ (See Scheme 1).

Scheme 1. Formation of Carbonic Acid and Associated Anions and Radicals.

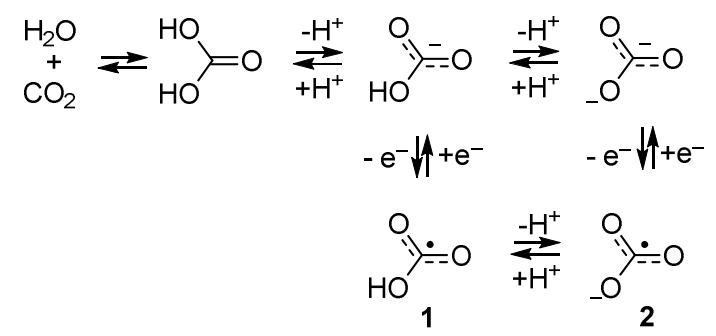

These species play important roles in geology, oceanology, atmospheric chemistry and of course in physiology. In blood serum and intracellular media these equilibria constitute the 'bicarbonate buffer system'. This is critical for maintaining the $\mathrm{pH}$ constant within the range 7.35-7.45 which is essential for optimum functioning of enzymes. ${ }^{1}$ Approximately $70 \%$ of $\mathrm{CO}_{2}$ is transported as bicarbonate in the human body (25.0 $\mathrm{mM}$ in serum and $14.4 \mathrm{mM}$ in intracellular media). ${ }^{2}$ When an electron is removed from bicarbonate or carbonate respectively, neutral bicarbonate radicals $\mathbf{1}$ or carbonate radical anions $\mathbf{2}$ are created. There are several enzymatic (and possibly nonenzymatic) ways these radicals can be produced in biological fluids. For example $\mathrm{CO}_{2}$ is one of peroxynitrite's primary biological targets producing $\mathrm{NO}_{2}$ and 2. ${ }^{3}$ Xanthine oxidase turnover of acetaldehyde and other substrates is also known to produce 2 . $^{4}$ Similarly it is recognized ${ }^{5}$ that the $\mathrm{Cu}, \mathrm{Zn}$ superoxide dismutase $/ \mathrm{H}_{2} \mathrm{O}_{2}$ system also generates 2 .
As shown in Scheme 1, the carbonate radical anion 2 forms a conjugate base/acid pair with the neutral bicarbonate radical 1. Apart from attempts to determine its $p K_{a}$, virtually nothing is known about the chemistry or biochemistry of the neutral bicarbonate radical itself. It was shown to be a strong acid, ${ }^{6}$ and a computational study ${ }^{7}$ suggested its $p K_{a}$ might be as low as -4 units. Because of this acidity it is generally assumed that carbonate radical anions $\mathbf{2}$ are the dominant partner of the pair in biological fluids. Carbonate radical anion $\mathbf{2}$ is a reactive oxygen species (ROS) that contributes to oxidative stress. ${ }^{8}$ It is an important oxidizing agent in aqueous solution, ${ }^{9}$ and its main bio-targets are polar species such as biothiols, nucleic acids, metalloproteins/proteins and glutathione. $^{10}$

Because $\mathrm{HOCO}_{2} \bullet$ is neutral, whereas ${ }^{-} \mathrm{OCO}_{2} \bullet$ is negatively charged, and the two radicals have very different extents of electron delocalization, their preferred reaction channels and reactivity are expected to be markedly different. Thus $\mathbf{2}$ is lipophobic, with the majority of its physiological reactions taking place in polar environments. Therefore, it should be a poor initiator of lipid peroxidation, due to its low diffusibility in hydrophobic environments. The neutral protonated radical 1 could well be the dominant form in non-polar hydrophobic lipid rich situations. Initiation of peroxidation is the likely role of $\mathbf{1}$ in structures such as membranes, vesicles, lowdensity lipo-protein particles (LDL) or lipid microdomains. However, as of yet, there is no research reporting peroxidation of lipids by $\mathbf{1}$. One reason for this is that the carbonate and bicarbonate precursors of $\mathbf{1}$ are only soluble in polar solvents so that even when $\mathbf{1}$ is formed it immediately deprotonates to 2. No lipid soluble precursor for $\mathbf{1}$ is currently known. To understand oxidative lipid and cell damage, with the resultant functional decline and associated degenerative conditions, a thorough study of the chemistry and biochemistry of both components of the carbonate/bicarbonate radical pair is much needed.

Radical $\mathbf{1}$ may be viewed as the first member of a homologous series with alkyl carbonate radicals: 
These neutral alkyl carbonate radicals are structurally similar to 1 so they, and particularly the methyl carbonate radical (7), are suitable models for $\mathbf{1}$. Several members of this series have been generated and precursors soluble in organic solvents, that is dialkyl peroxydicarbonates ${ }^{11}$ and oxime carbonates, ${ }^{12}$ are known. However, to our knowledge, the simplest member, methyl carbonate, has not yet been reported.

The objectives of this research were first to weigh up lipidsoluble precursors for radical $\mathbf{1}$. Second to investigate the structural integrity of $\mathbf{1}$, and of model $\mathrm{MeOC}(\mathrm{O}) \mathrm{O}^{\bullet}$ and related species, particularly in respect of the ease with which they decarboxylate:

$\mathrm{R}^{1} \mathrm{OC}(\mathrm{O}) \mathrm{O}^{\bullet} \rightarrow \mathrm{R}^{1} \mathrm{O}^{\bullet}+\mathrm{CO}_{2}$

An examination of specific reactions of these species with lipid components was also a priority. In each case both experimental and quantum-mechanical (QM) computational methods were employed. By these means insight into the reactivity of model $\mathrm{MeOC}(\mathrm{O}) \mathrm{O}^{\mathbf{*}}$, and of radicals $\mathbf{1}$ and $\mathbf{2}$, as well as new insights into the $p K_{a}$ of $\mathbf{1}$ was obtained. Understanding of the way 1 and $\mathbf{2}$ differ from hydroxyl radicals - the archetype ROS - in the type of reaction they undergo, and in their site selection with unsaturated fatty acids and cholesterol, was also obtained.

\section{EXPERIMENTAL STUDIES}

\section{Bicarbonate Radical (1) Precursors.}

Research with oxime carbonates $\mathbf{3}$ showed they release alkyl carbonate radicals $\mathrm{ROC}(\mathrm{O}) \mathrm{O} \cdot$ on photolysis. These compounds are safe and have long shelf-lives and are thus promising precursors for the study of $\mathrm{HOC}(\mathrm{O}) \mathrm{O} \bullet$ and $\mathrm{MeOC}(\mathrm{O}) \mathrm{O}^{\bullet}$ radicals. Compound $\mathrm{PhCMeC}=\mathrm{NOC}(\mathrm{O}) \mathrm{OH}$ (4) would be expected to release radical 1 on irradiation together with the much less reactive ${ }^{13,14,15}$ iminyl radical $\mathrm{PhMeC}=\mathrm{N}^{\bullet}(\mathrm{Im})$ (Scheme 2).

Scheme 2. Potential Lipid Soluble Precursors for Radical 1

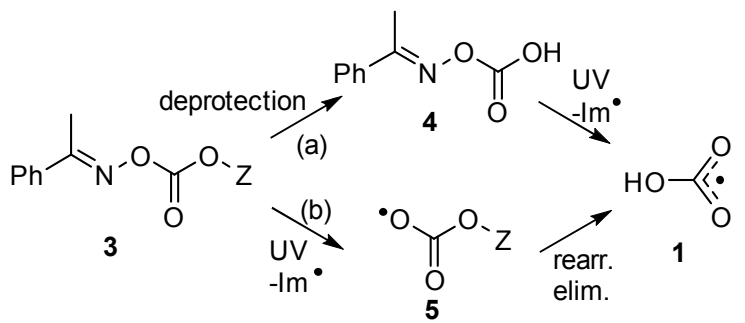

Deprotection protocols with various derivatives of $\mathbf{3}[(\mathrm{Z}=$ protecting group, route (a)] have not so far been successful; nor have experiments to generate radicals $\mathbf{5}$ that rearrange and/or eliminate to release 1 [route (b) in Scheme 2]. ${ }^{16} \mathrm{Be}-$ fore embarking on a project to further develop route (b) we decided to first forecast the structural integrity of $\mathbf{1}$, and to see how its reactivity would differ from 2 and from $\mathrm{HO}^{\bullet}$ radicals, by examination of model $\mathrm{MeOC}(\mathrm{O}) \mathrm{O}^{\bullet}$ radicals and by DFT computations.

\section{Methyl Carbonate Radical Additions to Aromatics and Decarboxylation Kinetics.}

The oxime carbonates $\mathbf{6} \mathbf{a}, \mathbf{b}$ were clear choices as precursors for the methyl carbonate (methoxycarbonyloxyl) radical 7 . They were prepared by the literature method ${ }^{12 a}$ from methyl chloroformate and the appropriate oxime. Solutions of each of $\mathbf{6 a}$ and $\mathbf{6 b}(0.1 \mathrm{~mol})$ in $t$-butylbenzene containing 4 methoxyacetophenone (MAP, 1 equiv.) as photosensitizer were purged with $\mathrm{N}_{2}$ and UV irradiated in the resonant cavity of an EPR spectrometer. Neither $\mathrm{MeOC}(\mathrm{O}) \mathrm{O}^{\bullet}$ radicals nor $\mathrm{MeO}^{\bullet}$ radicals will be directly detectable by EPR in solution. $^{11 \mathrm{a}, 17}$ The spectra actually disclosed the corresponding iminyl radical together with a second species having $g=$ $2.0026, a(1 \mathrm{H})=34.5, a(1 \mathrm{H})=13.1, a(1 \mathrm{H})=9.3, a(1 \mathrm{H})=8.1$, $a(1 \mathrm{H})=2.8 \mathrm{G}$. By analogy with literature data for other alkyl carbonate radicals $^{11,12}$ we identify this as the meta-adduct radical 8 from addition of 7 to the solvent (see Scheme 3 ).

Scheme 3. Generation and Reactions of Methyl Carbonate Radicals 7.

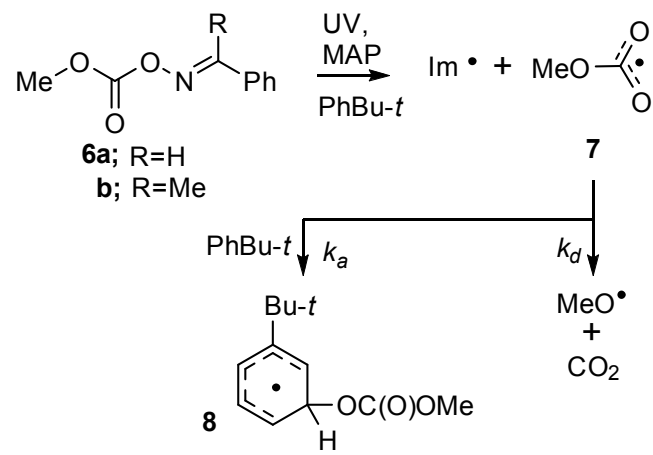

The concentration ratio $[8] /[\mathrm{Im}]$ was measured by simulation of spectra and is shown as a function of temperature in Figure 1.

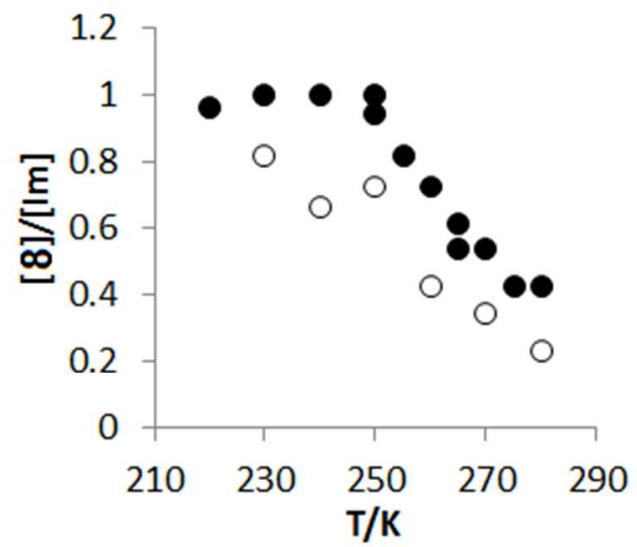

Figure 1. Data for Decarboxylation of $\mathrm{MeOC}(\mathrm{O}) \mathrm{O}^{\bullet}$ Radicals.

Filled circles: data from oxime carbonate $\mathbf{6 a}$ Open circles: data from oxime carbonate $\mathbf{6 b}$

With the $\mathbf{6 b}$ precursor (open circles) the $[\mathbf{8}] /[\mathrm{Im}]$ ratios were more scattered and less reliable because of the large difference in line-width between $\mathbf{8}$ and $\mathrm{Im}$ in this case and the greater extent of overlap of their spectra. We therefore gave more weight to the data from 6a. Equal numbers of Im and 7 radicals were formed in each initiation step and so the fact that the $[\mathbf{8}] /[\mathrm{Im}]$ ratio was close to 1 at low temperatures (Figure 1, closed circles) indicated that the meta-addition of radical 7 to the solvent was very fast and complete. It follows, therefore, that the amount of $\mathbf{8}$ equals the amount of $\mathbf{7}$ in solution. Above $\mathrm{T} \sim 250 \mathrm{~K}$ the $[8] /[\mathrm{Im}]$ ratio decreased and we attribute this to the onset of decarboxylative dissociation of 7 to $\mathrm{MeO}^{\circ}$ and $\mathrm{CO}_{2}$.

The rate constants of dissociation of $7\left(k_{d}\right)$ were determined from measurements of the concentrations of $\mathbf{8}$ and $\mathrm{Im}$ in the 
fall-off region. Making the Steady-State Approximation and assuming all termination steps were diffusion controlled with rate constant $2 k_{t}$ we obtained equ. (1): ${ }^{18}$

$$
k_{d} / 2 k_{t}=[\mathrm{MeO}]+[\mathrm{MeO}]^{2} /[7]
$$

Provided other reactions of 7 were insignificant $[7]=[8]$ and hence:

$$
k_{d} / 2 k_{t}=\{[\operatorname{Im}]-[8]\}+\{[\operatorname{Im}]-[8]\}^{2} /[\mathbf{8}]
$$

Iminyl radicals terminate at the diffusion rate; ${ }^{19}$ as do the other radicals in Scheme 4, and hence the use of Fischer's data for $2 k_{t}\left[\log A_{t}=11.63 \mathrm{M}^{-1} \mathrm{~s}^{-1}, E_{t}=2.25 \mathrm{kcal} \mathrm{mol}^{-1}\right]{ }^{20}$ appropriately corrected for the difference in solvent viscosity, ${ }^{21}$ was justified. Radical concentrations were determined from double integrations of the EPR spectra derived from precursor 6a in the fall-off region and a satisfactory Arrhenius plot was obtained (see Supporting Information) with parameters as follows:

$\log \left(A_{d} / \mathrm{s}^{-1}\right)=13.9 \pm 1.8, \quad E_{d}=14.6 \pm 2.2 \mathrm{kcal} \mathrm{mol}^{-1}$ $k_{d}(300 \mathrm{~K})=1.8 \times 10^{3} \mathrm{~s}^{-1}$

These results seem very reasonable because the measured activation barrier is close to experimental and to DFT computed barriers for dissociation of $\mathrm{PhCH}_{2} \mathrm{OC}(\mathrm{O}) \mathrm{O}^{\bullet}$ radicals $\left(12.9 \pm 2.0 \mathrm{kcal} \mathrm{mol}^{-1}\right){ }^{12 \mathrm{a}}$ It is evident therefore that 7 has sufficient structural integrity to take part in a range of chemical processes. Rate constants for $\mathrm{H}$-atom abstraction and addition reactions of alkyl carbonate radicals are of the order of ${ }^{1 \mathrm{~b}}$ $10^{7}$ to $10^{8} \mathrm{M}^{-1} \mathrm{~s}^{-1}$. Thus radical 7 with a $k_{d}$ of $1.8 \times 10^{3}$ will easily be persistent enough to engage in these processes at $300 \mathrm{~K}$ for substrate concentrations of $>10^{-4} \mathrm{M}$.

There are interesting implications of these findings for the chemistry of bicarbonate radicals 1 . These will dissociate by $\beta$-scission to $\mathrm{CO}_{2}$ and $\mathrm{HO}^{\bullet}$ radicals. The activation barriers and rates of radical $\beta$-scission reactions usually depend strongly on the thermodynamic stabilization of the released radical. $^{22}$ The $\mathrm{HO}^{\circ}$ radical is less thermodynamically stabilized than $\mathrm{MeO}^{\bullet}$ or $\mathrm{EtO}^{\bullet}$ by 13.6 and $13.4 \mathrm{kcal} \mathrm{mol}^{-1}$ respectively. ${ }^{23}$ This gives a strong indication that the barrier to decarboxylative $\beta$-scission of the $\mathrm{HOC}(\mathrm{O}) \mathrm{O}^{\bullet}$ radical 1 will be considerably higher than that of 7 and the lifetime of $\mathbf{1}$ in non-polar environments will be even greater. DFT computations, ${ }^{12}$ (see below) also predict a higher barrier. Once formed, therefore, bicarbonate radicals are expected to have ample lifetimes to attack lipid components and contribute, with other ROS, to their oxidative transformations. Our next step was to examine model reactions of radical 7 with organic substrates and lipid components so as to shed light on how bicarbonate radical oxidative processes could differ from those of $\mathrm{HO}^{\bullet}$ radicals and other ROS.

As shown above, addition of 7 to aromatics was rapid. We also found that 7 added very efficiently to furan, thiophene and derivatives thereof (Table 1; see Supporting Information for sample spectra). The addition was selective for the 2-(or 5)-positions and both 2- and 5-adduct radical isomers (9) were obtained in approximately equal amounts from 3methylthiophene. In no case was an adduct radical from attack at a 3-position observed although, because of the considerable noise levels, minor amounts would escape detection. Table 1. EPR Parameters of Adduct Radicals (9) of Methyl Carbonate Radicals and Heterocycles.*

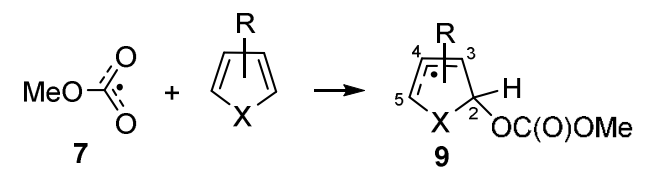

\begin{tabular}{l|l|l|l|l|l|l}
$\mathbf{X}, \quad \mathbf{R}$ & $\mathbf{T} / \mathbf{K}$ & $\boldsymbol{g}$-factor & $\boldsymbol{a}\left(\mathbf{H}^{2}\right)$ & $\boldsymbol{a}\left(\mathbf{H}^{3}\right)$ & $\boldsymbol{a}\left(\mathbf{H}^{4}\right)$ & $\boldsymbol{a}\left(\mathbf{H}^{5}\right)$ \\
\hline $\mathrm{O}, \quad \mathrm{H}$ & 240 & 2.0029 & 19.5 & 13.6 & 1.9 & 14.4 \\
\hline $\mathrm{O}, \quad 2-\mathrm{Me}$ & 290 & 2.0022 & 18.4 & 13.9 & 1.6 & $12.7(3 \mathrm{H})$ \\
\hline $\mathrm{O}, \quad 2-t-\mathrm{Bu}$ & 230 & 2.0030 & 19.7 & 13.9 & 1.7 & - \\
\hline $\mathrm{S}, \quad \mathrm{H}$ & 240 & 2.0046 & 18.6 & 11.9 & 2.3 & 13.7 \\
\hline $\mathrm{S}, \quad 3-\mathrm{Me}^{\S}$ & 230 & 2.0040 & 17.4 & $12.5(3 \mathrm{H})$ & 2.5 & 13.7 \\
\hline $\mathrm{S}, \quad 3-\mathrm{Me}^{\text {§ }}$ & 230 & 2.0040 & 18.1 & 11.2 & $2.4(3 \mathrm{H})$ & 14.0
\end{tabular}

* EPR hyperfine splitting (hfs) in Gauss. ${ }^{\S}$ Isomeric radicals from addition at C-2 and C-5.

It is noteworthy that addition of 7 to the rings was preferred to abstraction of the 'benzyl-like' $\mathrm{H}$-atoms of the $\mathrm{CH}_{3}$ groups attached to both heterocycle types. Reaction with toluene was also examined. The spectra were too weak for definitive analysis but appeared to show a mixture of ortho-, meta- and para-adduct radicals with again no sign of benzyl radicals from $\mathrm{H}$-abstraction by the $\mathrm{MOC}(\mathrm{O}) \mathrm{O}^{\bullet}$ radicals. GC-MS analysis of the photolysate supported this conclusion (see Supporting Information).

\section{Methyl Carbonate Radical Reactions with Lipid Components.}

Peroxidation, and the associated oxidative stress in organisms, is initiated when ROS damage lipid components of cells. $^{24}$ The mechanisms associated with this peroxidation have been intensively studied over many years. ${ }^{25,26}$ The hydroxyl radical is the most reactive ROS and it is well established that this species initiates much peroxidation. It abstracts $\mathrm{H}$-atoms from allylic sites in mono-unsaturated lipid components such as oleic acid and cholesterol and from bisallylic sites in di- and poly-unsaturated fatty acids (PUFA). Subsequent chain propagation proceeds through addition of oxygen to the $\mathrm{C}$-centered radicals, so generating peroxyl radicals that then abstract $\mathrm{H}$-atoms, thus producing hydroperoxides. Our aim was to establish if bicarbonate radicals 1 would initiate in this same way, simply augmenting the regular peroxidation process, or if they could initiate alternative oxidative sequences ending in novel metabolites.

Our first evidence that radicals 7 behave differently came from a study of their reaction with hex-1-ene. When a solution of oxime carbonate $\mathbf{6 b}$ and MAP in neat hex-1-ene was UV irradiated in the EPR cavity the spectrum showed the $\mathrm{PhMeC}=\mathrm{N} \cdot$ radical $(73 \%)$ and another radical $(27 \%)$ with EPR parameters: $g=2.0027 ; a(1 \mathrm{H})=21.0, a(4 \mathrm{H})=24.7 \mathrm{G}$ at $290 \mathrm{~K}$. We identify this as the adduct radical $\mathrm{CH}_{3}\left(\mathrm{CH}_{2}\right)_{3} \mathrm{CH} \cdot \mathrm{CH}_{2} \mathrm{OC}(\mathrm{O}) \mathrm{OMe}$. Surprisingly, none of the allylic radical from $\mathrm{H}$-abstraction adjacent to the double bond could be detected. The predominant process was addition to the $\mathrm{C}=\mathrm{C}$ double bond.

As a control experiment we examined the reaction of 7 with the fully saturated fatty acid derivative methyl stearate [ $n$ $\mathrm{C}_{17} \mathrm{H}_{35} \mathrm{C}(\mathrm{O}) \mathrm{OMe}$. The EPR spectrum taken during photolysis of a benzene solution $(0.1 \mathrm{M}$ in $6 \mathbf{b}$ and $0.16 \mathrm{M}$ in methyl stearate) at $292 \mathrm{~K}$ showed $\operatorname{Im}(87 \%)$ and a minor amount (13 $\%$ ) of a radical with $g=2.0028, a(1 \mathrm{H})=21.3, a(4 \mathrm{H})=24.7$ G. This is clearly a composite spectrum of the secondary radicals $-\mathrm{CH}_{2} \mathrm{CH}^{\bullet} \mathrm{CH}_{2}-\left(\mathbf{s}^{\bullet}\right)$ formed on $\mathrm{H}$-abstraction from all 14 of the methylene groups in the chain that are flanked on both sides by $\mathrm{CH}_{2}$ groups. This very weak spectrum contrasts with that reported for $\mathrm{H}$-atom abstraction from stearic acid by $t$-BuO ${ }^{\bullet}$ radicals (a model for ROS). ${ }^{27}$ In that case strong spectra of $\mathbf{s}^{\bullet}$ plus signals from the radicals $\alpha$-to the $\mathrm{COOH}$ 
group $\left(\mathrm{C}_{2}, \alpha\right.$-radicals $)$ and adjacent to the $\mathrm{CH}_{3}$ group $\left(\mathrm{C}_{17}, \omega-1\right.$ radicals) were observed and indicated that $t$ - $\mathrm{BuO}^{\bullet}$ radicals abstracted rapidly and unselectively from every site.

The EPR spectrum obtained from UV photolysis of a similar solution containing $\mathbf{6 b}$, methyl oleate (10) and MAP in $\mathrm{PhH}$ at $292 \mathrm{~K}$ is shown in Figure 2 (top).

In addition to Im radicals, a second radical with $g=2.0025$, $a(2 \mathrm{H})=26.1, a(1 \mathrm{H})=21.5, a(1 \mathrm{H})=13.8 \mathrm{G}$ was observed. This was readily identified as the adduct radical $(\mathbf{1 1 a}, \mathbf{b})$ of $\mathrm{MeOC}(\mathrm{O}) \mathrm{O}^{\bullet}$ to the double bond of the methyl oleate (Scheme 4). A minor amount of secondary radicals $\mathbf{s}^{\bullet}(g=2.0025$, $a(1 \mathrm{H})=21.5, a(4 \mathrm{H})=24.5 \mathrm{G})$ was also observed. Spectra were obtained at several temperatures down to $220 \mathrm{~K}$ (with toluene as solvent for lower temperatures). Small amounts of peroxyl radicals (p, Figure 2, bottom) were detected with this solvent. The relative concentrations of the radicals determined at each temperature were as shown in Table 2. None of allylic type radical $\mathbf{1 2}$ from $\mathrm{H}$-abstraction adjacent to the double bond (at $\mathrm{C}_{8}$ or $\mathrm{C}_{11}$ ) was detected. ${ }^{28}$ The relatively large amounts of $\mathbf{1 1}$ showed that addition of radical $\mathbf{7}$ was rapid even at $220 \mathrm{~K}$.

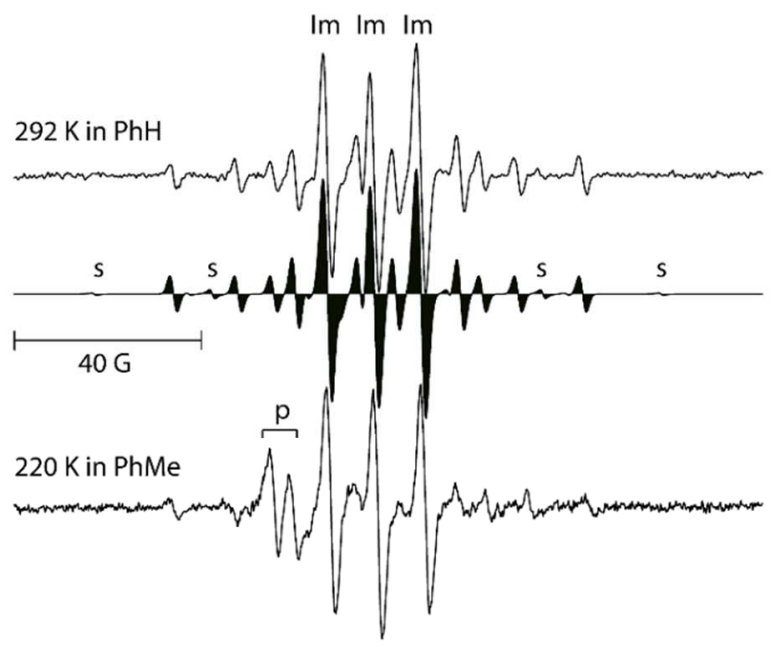

Figure 2. EPR Spectra from $\mathbf{6 b}$ and methyl oleate in solution.

Top: experiment at $292 \mathrm{~K}$ in $\mathrm{PhH}$

Centre: Computer simulation; "s" indicates prominent peaks of secondary radicals, "Im" indicates $\mathrm{PhMeC}=\mathrm{N}^{\bullet}$ radicals.

Below: experiment at $220 \mathrm{~K}$ in PhMe; 'p' indicates peroxyl radicals.

Table 2. Relative concentrations of radicals obtained on photolysis of $\mathbf{6 b}$ and methyl oleate.

\begin{tabular}{l|l|l|l|l}
$\mathrm{T} / \mathrm{K}$ & Solvent & $\mathbf{I m}(\%)$ & $\mathbf{1 1 a}, \mathbf{b}(\%)$ & $\mathbf{s}^{\bullet}(\%)$ \\
\hline 292 & $\mathrm{PhH}$ & 60 & 36 & 4 \\
\hline 273 & $\mathrm{PhH}$ & 51 & 49 & $<2$ \\
\hline 240 & $\mathrm{PhMe}$ & 54 & 46 & $<2$ \\
\hline 220 & $\mathrm{PhMe}$ & 63 & 37 & $<2$
\end{tabular}

There was little change in the spectra up to $292 \mathrm{~K}$ showing that the major pathway remained addition and that even dis- sociation of $\mathrm{MeOC}(\mathrm{O}) \mathrm{O}^{\bullet}$ did not compete. The small proportion of $\mathbf{s}^{\bullet}$ observed at $292 \mathrm{~K}$ demonstrated $\mathrm{MeOC}(\mathrm{O}) \mathrm{O}^{\bullet}$ was less selective for addition at higher temperatures such that some $\mathrm{H}$-atom abstraction occurred.

The two radicals $\mathbf{1 1 a}$ and $\mathbf{1 1 b}$ formed on addition of $\mathrm{MeOC}(\mathrm{O}) \mathrm{O}^{\bullet}$ to either end of the double bond of $\mathbf{1 0}$ have extremely similar structures in the vicinity of their radical centres. Their EPR spectra will be indistinguishable and the experimental spectrum is probably a 50:50 mixture of the two. $^{29}$ The $13.8 \mathrm{G}$ doublet hyperfine splitting (hfs) is from the single $\mathrm{H}^{\beta}$ of $\mathbf{1 1}$ and its small magnitude (and the fact that this decreased to $12.5 \mathrm{G}$ at $220 \mathrm{~K}$ ) indicates this $\mathrm{H}^{\beta}$ lies close to the nodal plane of the p-orbital containing the unpaired electron. We can conclude that the preferred conformation is as shown in 11as. ${ }^{30}$ The majority of initiation in oleate peroxidation by other ROS types occurs by $\mathrm{H}$-atom abstraction adjacent to the double bond. For $t$ - $\mathrm{BuO}^{\bullet}$ radicals with oleate, for example, the allylic type species $\mathbf{1 2}$ (plus minor $\mathbf{s}^{\circ}$ ) were the only radicals detected by EPR spectroscopy. ${ }^{31}$ There is therefore a striking contrast between the preferred addition reaction of $\mathrm{MeOC}(\mathrm{O}) \mathrm{O}^{\bullet}$ radicals to $\mathrm{C}_{9}$ and $\mathrm{C}_{10}$ of oleate and $\mathrm{H}$-abstraction from $\mathrm{C}_{8}$ and $\mathrm{C}_{11}$ preferred by other ROS.

\section{Scheme 4. Reaction of Methyl Carbonate Radical with Methyl Oleate.}

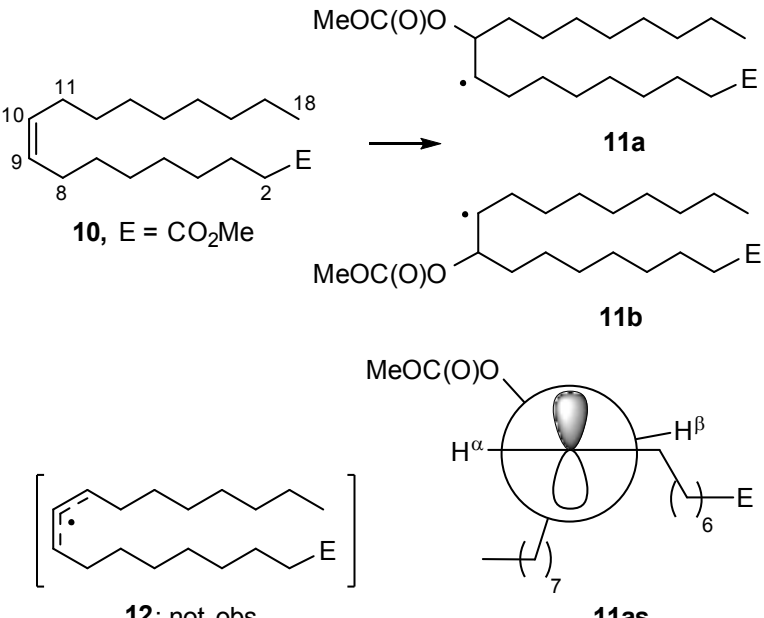

The EPR spectrum obtained during a similar photolysis of $\mathbf{6 b}$ and the doubly unsaturated methyl linoleate $\mathbf{1 3}$ in $\mathrm{PhH}$ at 293K (Figure 3) contained Im (56\%), adduct radical 14 [28 $\%, g=2.0025, a(2 \mathrm{H})=25.8, a(1 \mathrm{H})=21.7, a(1 \mathrm{H})=14.4 \mathrm{G}]$ and also pentadienic radical $15(16 \%, g=2.0025, a(2 \mathrm{H})=$ $3.4, a(4 \mathrm{H})=8.0, a(2 \mathrm{H})=10.0, a(1 \mathrm{H})=11.1 \mathrm{G}]$. Ester 13 contains four essentially equivalent sites for radical addition and the resulting radicals would have indistinguishable EPR spectra so the spectrum of $\mathbf{1 4}$ is probably a composite of all four. Allylic radicals are thermodynamically stabilized by about $10 \mathrm{kcal} \mathrm{mol}^{-1}$ more than secondary alkyl radicals and pentadienic radicals are more stabilized by ${ }^{23}$ about $15 \mathrm{kcal}$ mol $^{-1} \mathrm{H}$-atom abstraction from $\mathrm{C}_{11}$ in $\mathbf{1 3}$ will be correspondingly more facile. It is understandable therefore that the activation energy for bis-allylic $\mathrm{H}$-abstraction by $\mathrm{MeOC}(\mathrm{O}) \mathrm{O} \bullet$ is 
sufficiently lowered for this to compete with addition.

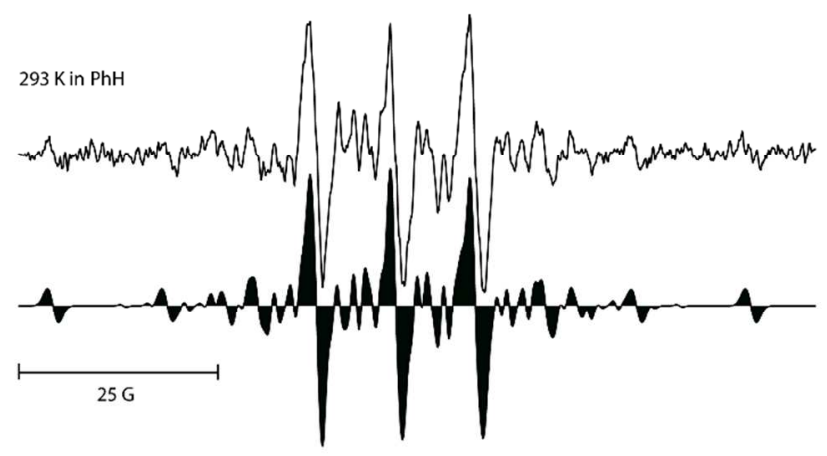

Figure 3. EPR Spectra from $\mathbf{6 b}$ and Methyl Linoleate $\mathbf{1 3 .}$

Top: experiment at $293 \mathrm{~K}$ in $\mathrm{PhH}$

Below: simulation including Im, adduct radical $\mathbf{1 4}$ and pentadienic radical 15.

Again there is a noteworthy contrast between $\mathrm{MeOC}(\mathrm{O}) \mathrm{O}^{*}$ and $t-\mathrm{BuO}^{\circ}$ (and other ROS) that exclusively abstracted $\mathrm{H}$ atoms from fatty ester $1 \mathbf{1 3}^{31}$

The EPR spectra obtained from similar reactions of $\mathbf{6 a}$ and $\mathbf{6 b}$ with methyl $\gamma$-linolenate (16) contained mostly signals from the pentadienic radicals $(\mathbf{1 7 a}, \mathbf{b})$ resulting from abstraction of $\mathrm{H}$-atoms at $\mathrm{C}_{8}$ and $\mathrm{C}_{11}[50 \%: g=2.0027, a(2 \mathrm{H})=3.4, a(4 \mathrm{H})$ $=7.9, a(2 \mathrm{H})=10.0, a(1 \mathrm{H})=11.3 \mathrm{G}]$. Only minor amounts of the adduct radicals were detected (see Supporting Information).

Scheme 5. Reaction of Methyl Carbonate Radical with Methyl Linoleate (13) and Methyl $\gamma$ Linolenate (16)
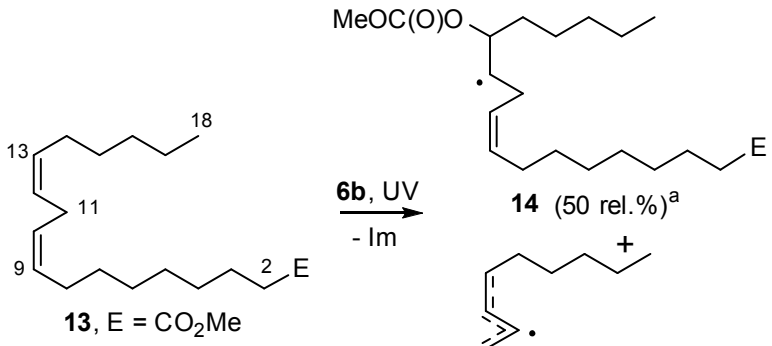

$14(50 \mathrm{rel} . \%)^{\mathrm{a}}$

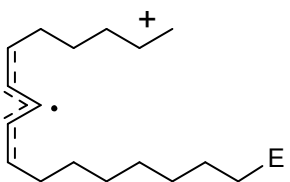

$15(28 \text { rel. \% })^{\mathrm{a}}$
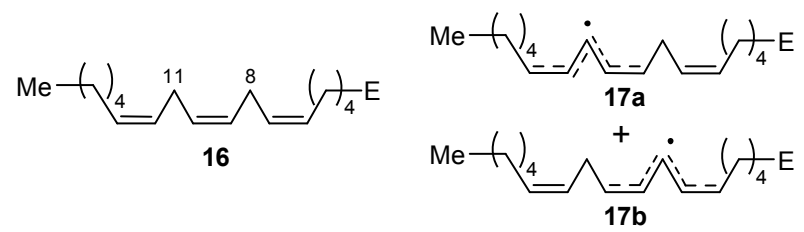

Cholesterol (18, Scheme 6) and its derivatives are also important oxidizable components of lipid structures. ${ }^{26,32}$ Peroxidation is initiated by transfer of an $\mathrm{H}$-atom from $\mathrm{C}_{7}$ and the resulting allylic radicals $\mathbf{2 1}$ have been characterised by EPR spectroscopy. ${ }^{33} \mathrm{H}$-transfer from $\mathrm{C}_{4}$ has also been reported as well as peroxyl radical addition to the double bond at $\mathrm{C}_{6}$. followed by epoxide formation via an $\mathrm{S}_{\mathrm{H}}$ i process. ${ }^{34}$
Scheme 6. Reaction of Methyl Carbonate Radical with Cholesterol.

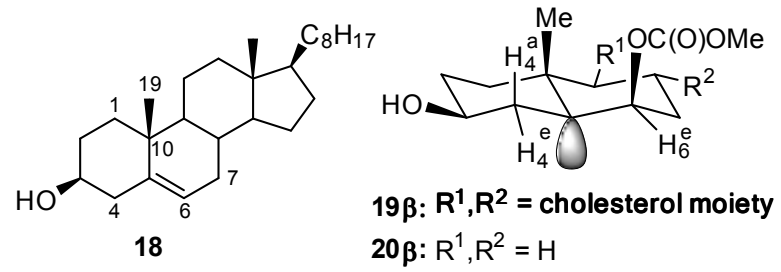

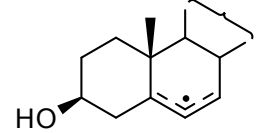

21 not observed

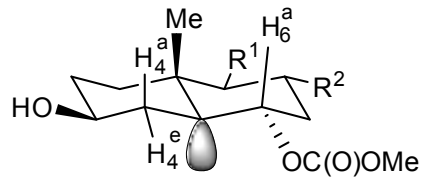

$19 \alpha: R^{1}, R^{2}=$ cholesterol moiety

$20 \alpha: R^{1}, R^{2}=H$

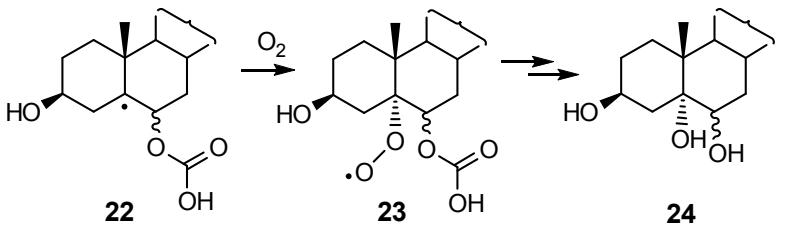

A solution of cholesterol $(0.13 \mathrm{M})$ and $\mathbf{6 b}(0.10 \mathrm{M})$ in $\mathrm{PhH}$ at $274 \mathrm{~K}$ on UV irradiation gave rise to the EPR spectrum of Figure 4.

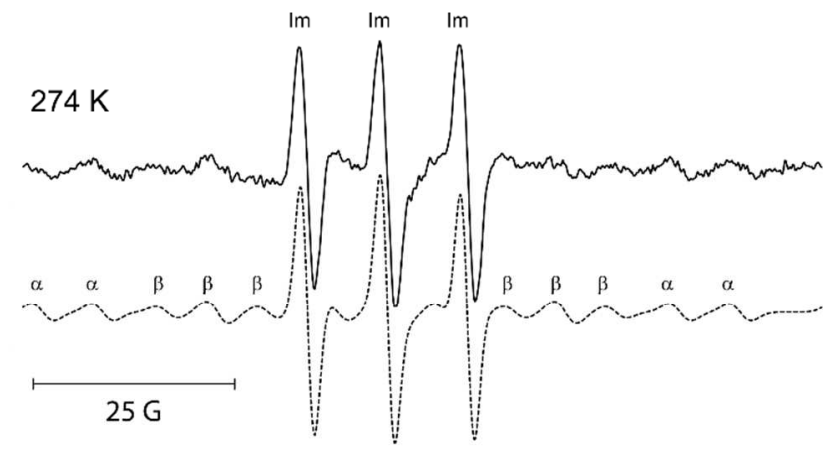

Figure4. EPR Spectra from $\mathbf{6 b}$ and Cholesterol in $\mathrm{PhH}$ at $274 \mathrm{~K}$.

Top: experimental spectrum during UV irradiation.

Below: simulation including Im and adduct radicals $19 \alpha$ and $19 \beta$ (prominent peaks marked $\alpha$ and $\beta$ respectively).

Simulation showed this spectrum to be a composite of $\operatorname{Im}(58$ $\%$ ) and two additional radicals both having $g$-factors of 2.0028 (characteristic of C-centered species) with the hfs in Table 3. None of the allylic radical 21 was detectable. To assist in identifying these species the structures and hfs of model adduct radicals $\mathbf{2 0} \boldsymbol{\alpha}$ and $\mathbf{2 0} \boldsymbol{\beta}$ were obtained from DFT computations at the UB3LYP/6-311+G(2d,p) level followed by single point energies with UB3LYP/aug-cc-pvtz. Table 3 demonstrates the close correspondence between the computed hfs for models $\mathbf{2 0} \boldsymbol{\beta}, \boldsymbol{\alpha}$ and the experimental parameters of the two spectral components. We conclude that these are adduct radical $\mathbf{1 9} \boldsymbol{\beta}$ (29 rel. \%) generated from approach by 7 from the $\beta$-face of the ring system and $19 \alpha$ (43 rel. \%) generated by approach from the $\alpha$-face. These are bridgehead radicals and, as expected, the hfs for the equatorial $\mathrm{H}^{\mathrm{e}}$-atoms are com- 
paratively small because they lie close to the nodal plane of the SOMO. The somewhat smaller amount of $19 \beta$ compared to $19 \alpha$ is consistent with minor steric shielding of the $\beta$-face by the $\mathrm{C}_{19}$ Me group.

Table 3. EPR Parameters of Radicals from Addition of $\mathrm{MeOC}(\mathrm{O}) \mathrm{O}^{\bullet}$ to Cholesterol $\mathbf{1 8}$ (at $\mathrm{C}_{6}$ ) and Model Species

\begin{tabular}{c|c|c|c|c|c} 
Radical & Method & $a\left(\mathrm{H}_{4}{ }^{\mathrm{e}}\right)$ & $a\left(\mathrm{H}_{4}{ }^{\mathrm{a}}\right)$ & $a\left(\mathrm{H}_{6}{ }^{\mathrm{e} \text { or a }}\right)$ & $a\left({ }_{3} \mathrm{H}_{19}\right)$ \\
\hline $\mathbf{1 9} \boldsymbol{\beta}(\mathbf{2 9} \%)^{\&}$ & expt. & 6.1 & 43.5 & 6.5 & $<1.4$ \\
\hline $\mathbf{2 0} \boldsymbol{\beta}$ & DFT $^{*}$ & 5.3 & 42.1 & 6.2 & 1.4 \\
\hline $\mathbf{1 9 \alpha}(43 \%)^{\&}$ & expt. & 7.5 & 42.8 & 36.9 & $<1.4$ \\
\hline $\mathbf{2 0} \alpha$ & DFT $^{*}$ & 6.2 & 42.2 & 35.7 & 1.0
\end{tabular}

\& \% relative to Im concentration. ${ }^{*}$ DFT isotropic Fermi contact hfs in Gauss: geometry opt. at UB3LYP/6$311+G(2 d, p)$ level with single point computation with the UB3LYP/aug-cc-pvtz method; note that all other computed hfs $\leq 1.0 \mathrm{G}$.

Radicals 1 and 7 are expected to exhibit very similar reactivities because they have very similar geometrical and electronic structures $\left({ }^{2} \mathrm{~A}^{\prime}\right.$ states). According to optimizations and natural population analyses at CAM-B3LYP/6-31G(d,p) and CAM$\mathrm{B} 3 \mathrm{LYP} / 6-311+\mathrm{G}(2 \mathrm{~d}, \mathrm{p})$ levels, respectively, the CO distances are the same within $1 \mathrm{pm}$, and atomic charges and spin densities of the terminal $\mathrm{O}$ atoms are identical within 0.01e. (See Figure S19 in the SI for a detailed comparison). By analogy therefore, bicarbonate radical 1 is expected to add to $\mathrm{C}_{6}$ of cholesterol to produce the isomeric radicals 22 (Scheme 6). In a lipid structure, propagation of the peroxidation process will proceed by trapping oxygen and formation of peroxyl radicals 23. Peroxyls are reductively converted to alcohols. ${ }^{35}$ Furthermore, mono-esters of carbonic acid, such as $\mathbf{2 3}$ rapidly decarboxylate. ${ }^{36}$ A major metabolite from peroxidation by bicarbonate radicals will therefore be the cholestane-3,5,6triol isomer pair 24. Further oxidation to $3 \beta, 5 \alpha$-dihydroxycholestan-6-one and isomers may also take place. ${ }^{37}$ Cholestane-3,5,6-triols, particularly cholestane- $3 \beta, 5 \alpha, 6 \beta$-triol, have been isolated from a number of natural products, ${ }^{38}$ and are biologically active in a variety of ways. ${ }^{39}$ In contrast, peroxidation via the allylic radical $\mathbf{2 1}$ produces $7 \alpha$ - and $7 \beta$ hydroxycholesterol and 7-ketocholesterol as well as other metabolites. ${ }^{26}$ Note, however, that some isomers of $\mathbf{2 4}$ can also be formed, in the absence of bicarbonate radicals, from peroxyl radical addition at $\mathrm{C}_{6}$, subsequent 5,6-epoxide formation and reductive epoxide ring opening. ${ }^{26 a}$

\section{QM COMPUTATION OF BICARBONATE AND METHYL CARBONATE PROPERTIES}

A QM computational study was undertaken in order to gain further insight into the structures, skeletal integrity and acidity of the $\mathbf{1} \leftrightarrow \mathbf{2}$ pair of radicals. From an initial validation study it appeared that the CAM-B3LYP functional ${ }^{40}$ could reproduce high-level ab initio benchmarks best (see Experimental Section below and Supporting Information for details), therefore it was chosen to study decarboxylation and deprotonation reactions.
DFT Study of Alkyl- and Bi-carbonate Decarboxylation

To obtain theoretical insight into how dissociation of $\mathrm{ROC}(\mathrm{O}) \mathrm{O}^{\bullet}$ radicals into $\mathrm{CO}_{2}$ and $\mathrm{RO}^{\bullet}$ depends on the nature of $\mathrm{R}$ we carried out computations with the species shown in Table 4. In accord with expectation for neutral $\mathrm{ROC}(\mathrm{O}) \mathrm{O}^{\bullet}$ radicals, non-polar ( $n$-hexane), moderately polar (DCM) and even highly polar (water) solvents had minimal effects on the thermodynamic and kinetic energy parameters (Table 4). The dissociations for $\mathrm{R}=$ alkyl were computed to be exothermic and their $\Delta G_{298}$ values were even more negative because of the increase in entropy accompanying $\beta$-scission. However, substantial energies of activation $\left(\Delta H^{*}\right)$ and free energies of activation $\left(\Delta G^{*}\right)$, were obtained for $\mathrm{R}=\mathrm{Me}$, Et and $\mathrm{Bn}$. This agrees with the significant radical lifetimes demonstrated by EPR spectroscopy. Confidence in the validity of the DFT computations was heightened by the good agreement of the computed $\Delta H^{*}$ values and experiment. Thus, for methyl carbonate radicals 7 the DFT computed $\Delta H^{t}$ values of 13.6 and $13.5 \mathrm{kcal} \mathrm{mol}^{-1}$, for gas and $n$-hexane respectively, were both within the error limits of our experimental Arrhenius activation energy of $14.6 \pm 2.2 \mathrm{kcal} \mathrm{mol}^{-1}$ in $t$-BuPh (see above). Similarly, for $\mathrm{R}=\mathrm{Bn}$, the DFT $\Delta H^{*}$ values of 13.2 and 12.7 kcal $\mathrm{mol}^{-1}$ in gas and $n$-hexane were also close to the experimental Arrhenius activation energy of $12.9 \pm 2.0 \mathrm{kcal} \mathrm{mol}^{-1}$.

This lends credence of the computed results for the bicarbonate radical itself. For this species (1) dissociation was found to be endothermic and only marginally exoergonic (by $\sim-3.5 \mathrm{kcal} \mathrm{mol}^{-1}$, Table 4). Furthermore the computed $\Delta H^{*}$ and $\Delta G^{\ddagger}$ activation barriers $\left(19.6-21.5 \mathrm{kcal} \mathrm{mol}^{-1}\right)$ were substantially greater (by $6.5 \mathrm{kcal} \mathrm{mol}^{-1}$ in the gas phase) than those for alkyl carbonate radicals. As mentioned above, the Radical Stabilization Energy (RSE) of the released $\mathrm{HO}^{\bullet}$ radical is less than that of $\mathrm{MeO}^{\bullet}$ or $\mathrm{EtO}^{\bullet}$ by 13.6 and $13.4 \mathrm{kcal}$ $\mathrm{mol}^{-1}$ respectively. It appears, therefore that the $\beta$-scission barrier for bicarbonate exceeds that of methyl carbonate radicals by just under half the difference in their RSEs and this makes good sense.

Table 4. DFT Computed Reaction Enthalpies $\left(\Delta H_{298}\right)$, Free Energies $\left(\Delta G_{298}\right)$ and Activation Parameters $\Delta H^{\ddagger}{ }_{298}, \Delta G^{\ddagger}{ }_{298}$ for $\mathrm{CO}_{2}$ loss from $\mathrm{RO}-\mathrm{CO}_{2}{ }^{\bullet}$ Radicals. ${ }^{\mathrm{a}}$

\begin{tabular}{|c|c|c|c|c|c|c|}
\hline $\mathbf{R}$ & DFT $^{\mathbf{b}}$ & Medium & $\Delta H_{298}$ & $\Delta G_{298}$ & $\Delta H^{\ddagger}{ }_{298}$ & $\Delta G_{298}^{\ddagger}$ \\
\hline$\overline{\mathrm{H}}$ & A & Gas & 5.6 & $-3 \cdot 3$ & 20.5 & 21.1 \\
\hline $\mathrm{H}$ & CBS-QB3 & Gas & $3 \cdot 4$ & $-5 \cdot 0$ & 21.0 & 20.6 \\
\hline $\mathrm{H}$ & $\mathrm{G}_{4}$ & Gas & 2.2 & -6.2 & 19.9 & 19.6 \\
\hline$\overline{\mathrm{H}}$ & A & n-hexane & $5 \cdot 3$ & $-3 \cdot 5$ & 20.7 & 21.3 \\
\hline $\mathrm{H}$ & A & DCM & $5 \cdot 4$ & $-3 \cdot 5$ & 20.8 & 21.5 \\
\hline $\mathrm{H}$ & A & $\mathrm{H}_{2} \mathrm{O}$ & 5.4 & $-3 \cdot 5$ & 20.9 & 21.5 \\
\hline $\mathrm{Me}$ & A & Gas & -7.2 & $-17 \cdot 4$ & 13.6 & 13.0 \\
\hline $\mathrm{Me}$ & A & n-hexane & $-7 \cdot 4$ & -17.6 & 13.5 & 13.0 \\
\hline $\mathrm{Me}$ & A & DCM & -7.6 & -17.8 & 12.8 & 12.3 \\
\hline$\overline{\mathrm{Me}}$ & A & $\mathrm{H}_{2} \mathrm{O}$ & $-7 \cdot 7$ & -17.8 & 12.6 & 12.2 \\
\hline Et & A & Gas & -6.1 & -15.9 & 12.8 & 11.9 \\
\hline Et & A & n-hexane & -6.8 & -17.0 & 14.2 & 13.4 \\
\hline$\overline{E t}$ & A & DCM & $-7 \cdot 3$ & -17.6 & 13.9 & 13.0 \\
\hline$\overline{\mathrm{Et}}$ & A & $\mathrm{H}_{2} \mathrm{O}$ & -7.6 & -17.8 & 12.7 & 11.8 \\
\hline
\end{tabular}




\begin{tabular}{l|l|l|l|l|l|l}
$\mathrm{Bn}$ & $\mathrm{A}$ & Gas & -7.3 & -18.4 & 13.2 & 12.9 \\
\hline $\mathrm{Bn}$ & $\mathrm{A}$ & $n$-hexane & -7.9 & -19.0 & 12.7 & 12.3 \\
\hline $\mathrm{Bn}$ & $\mathrm{A}$ & $\mathrm{DCM}$ & -8.3 & -19.4 & 11.8 & 11.5 \\
\hline $\mathrm{Bn}$ & $\mathrm{A}$ & $\mathrm{H} 2 \mathrm{O}$ & -8.4 & -19.4 & 11.5 & 11.2 \\
a Values in kcal mol ${ }^{-1}$ \\
b "A" signifies the CAM-B3LYP/6-311+G(2d,p)//CAM- \\
B3LYP/6-31G(d,p) method.
\end{tabular}

Assuming $\log \left(A_{d} / \mathrm{s}^{-1}\right) \approx 13$, typical of first-order dissociations, and an activation barrier of ca. $20 \mathrm{kcal} \mathrm{mol}^{-1}$ for $\mathrm{HOC}(\mathrm{O}) \mathrm{O}^{\circ}$ $\left(1\right.$, Table 4) leads to an estimated $k_{d}(300 \mathrm{~K}) \sim 0.027 \mathrm{~s}^{-1}$ and a half-life of $\sim 25 \mathrm{~s}$. This makes it abundantly clear that $\mathrm{HOC}(\mathrm{O}) \mathrm{O}^{\bullet}$ radicals possess sufficient structural integrity to initiate multiple oxidative chains in a biological environment. Next we turn to the expected acidity of this species in water.

\section{Acidity of the Bicarbonate Radical}

The acidities of oxoacids $\mathrm{XO}_{\mathrm{p}}(\mathrm{OH})_{\mathrm{q}}$ increase as the number of oxygen ligands ' $p$ ' increases. This reflects increasing resonance stabilization of the negative charge in the conjugate bases. Bell's Rule for such acids $\left[p K_{a}=8-5 \mathrm{p}\right]^{41}$ applied to the bicarbonate radical suggests a $p K_{a}$ of about -2 units. Recent experimental studies of the carbonate radical using optical pulse radiolysis, ${ }^{6 c}$ time-resolved resonance Raman spectroscopy $^{6 b}$ and EPR spectroscopy ${ }^{6 a}$ all indicate the bicarbonate radical is highly acidic, with a $p K_{a}$ below zero. However, it has not been possible to experimentally determine the value.

Calculation of $p K_{a}$ values is very computationally demanding, because an error of only $1.4 \mathrm{kcal} \mathrm{mol}^{-1}$ in the free energy of deprotonation equates to an error of $1 p K_{a}$ unit at room temperature. Nevertheless, Armstrong et al. ${ }^{7}$ employing thermodynamic cycles and high level ab initio calculations, predicted a $p K_{a}$ of $-4.1 \pm 1$ units.

The main sources of error are the choice (and uncertainty) of the required free energy of hydration of the proton (usually taken from experiment) and the neglect of specific intermolecular interactions between the solvent and the conjugate acids and bases. To circumvent these problems, and in the spirit of Pulay and co-workers, ${ }^{42}$ we predicted the $p K_{a}$ of 1 based on linear correlation of computed deprotonation free energies $\Delta G_{A-H A}$ with experimental $p K_{a} s$, using a set of twelve small carboxylic acids as reference. Gas- and aqueous-phase free energies of deprotonation (CAM-B3LYP and CPCM methods) as well as the correlations with experimental $p K_{a} s$ are collected in the Supporting Information. This procedure was designed to minimize any systematic errors in the individual predicted $p K_{a}$ data.

Linear regression gave $p K_{a}=0.151 \Delta G_{A-H A}-47.10\left(\mathrm{R}^{2}=\right.$ $0.932)$ and $p K_{a}=0.213 \Delta G_{A-H A}+0.428\left(\mathrm{R}^{2}=0.919\right)$ for the gas and aqueous phase data respectively (see Supporting Information). Extrapolation to the computed $\Delta G_{A-H A}$ for the bicarbonate radical afforded $p K_{a} s$ of -0.39 and -0.69 from the gas and aqueous correlations, respectively. These estimates imply high acidity, although Bell's rule and previous computed values afforded even more negative values.

A possible shortcoming of such simple linear correlations is that they might become less reliable for very small and strong acids such as $\mathbf{1}$, where specific interactions with the solvent would be most pronounced for the conjugate base with its very high charge density ( 2 in our case). One way to account for this would be to refine the deprotonation energies by in- cluding specific micro-solvating water molecules and check for convergence with increasing number of solvent molecules. The applicability of this approach to strong acids, however, is limited by their tendency to ionize spontaneously with just a few water molecules. $\mathrm{HCl}$, for example, has been shown by experiment and DFT computations to dissociate upon addition of just four water molecules into a $\mathrm{Cl}^{-}\left(\mathrm{H}_{2} \mathrm{O}\right)_{3}\left(\mathrm{H}_{3} \mathrm{O}^{+}\right)$"solvent-separated ion pair" (SSIP) in the gas phase. ${ }^{43}$ As expected, we observed the same type of spontaneous dissociation during attempted optimization of microhydrated clusters of 1 (see below), precluding quantitative assessment of the driving force for deprotonation upon hydration.

Several theoretical studies on microhydration of strong HX acids $(\mathrm{X}=\mathrm{F}, \mathrm{Cl}, \mathrm{Br}, \mathrm{I}){ }^{44}$ perchloric, ${ }^{45}$ formic, ${ }^{46}$ nitric, ${ }^{47}$ trifluoroacetic, ${ }^{48}$ sulfuric $^{49}$ and oxalic ${ }^{50}$ acids have established that, for strong mineral acids, indeed only a few microsolvating water molecules were needed to cause complete ionization. Furthermore a trend towards a smaller number of water molecules required for ionization $\left(N_{a q}{ }^{i}\right)$ as the acid increased in acidity, was noted. ${ }^{45}$ Theoretical estimation of $N_{a q}{ }^{i}$ is by no means easy because the number of possible conformations increases sharply as the number of water molecules increases. The potential energy surfaces for the interaction of $\mathrm{HA}$ with $\mathrm{H}_{2} \mathrm{O}$ are rather shallow leading to difficulties in establishing what are just local rather than global minima. Not surprisingly, as the foregoing literature demonstrates, some differences in $N_{a q}{ }^{i}$ have been reported for particular acids. A recent insightful article by Leopold surveys both theoretical and experimental approaches. ${ }^{51}$ A plot of experimental $p K_{a}$ values against $N_{a q}{ }^{i}$, from published theoretical studies, is shown in Figure 5. The data was taken from high level computations and, although alternative values can be found, high quality $N_{a q}{ }^{i}$ don't differ from the chosen values by more than 1 unit. Thus we feel the trend that emerges is real.

In Leopold's article ${ }^{51}$ spontaneous ionization of small acid-water clusters is qualitatively rationalized in terms of a thermodynamic cycle involving the energy for proton transfer from the neutral acid to $\mathrm{H}_{2} \mathrm{O}$ and hydration energies of the various neutral and ionic species involved. Because hydration stabilizes the ionization products more strongly than the neutral precursors, it is entirely plausible (at least for strong acids) that the higher the protontransfer energy the more water molecules are needed to overcome this. One may thus expect $N_{a q}{ }^{i}$ to correlate, at least qualitatively, with the gas-phase acidities (which vary appreciably for the acids studied, see Table S4 in the SI) and, hence, with $p K_{a}$. 


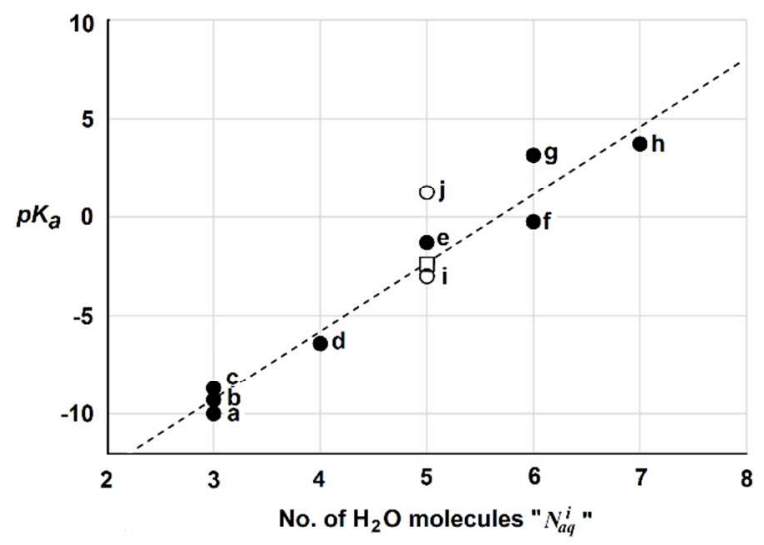

Figure 5. Plot of experimental $p K_{a} \mathrm{~s}$ of strong acids HX vs. computed no. of microsolvating $\mathrm{H}_{2} \mathrm{O}$ molecules required to induce their ionization. a; $\mathrm{HClO}_{4}$, b; $\mathrm{HI}, \mathrm{c} ; \mathrm{HBr} ; \mathrm{d} ; \mathrm{HCl}$, e; $\mathrm{HNO}_{3}$, f; $\mathrm{CF}_{3} \mathrm{CO}_{2} \mathrm{H}, \mathrm{g} ; \mathrm{HF}, \mathrm{h} ; \mathrm{HCO}_{2} \mathrm{H}, \mathrm{i} ; \mathrm{H}_{2} \mathrm{SO}_{4}$, j; oxalic acid (see text for literature references). Open square; $\mathrm{HOC}(\mathrm{O}) \mathrm{O}^{\bullet}$ radical (1).

The trend is remarkably linear; perhaps surprisingly so in view of the digital (integer) nature of $N_{a q}{ }^{i}$. Possibly nonlinearity will become apparent once data for a larger sample size becomes available. Straightforward linear regression of the data for the mono-protic acids yields the following relationship (3) with $\mathrm{R}^{2}=0.959$ :

$p K_{a}=3.46 N_{a q}{ }^{i}-19.65$

Our objective, therefore, was to compute the number of microsolvating water molecules needed to bring about ionization of bicarbonate radical and hence obtain a further estimate of its $p K_{a}$.

Maity and co-workers ${ }^{52}$ had reported structures for microsolvated carbonate radical anion clusters $\left[\mathrm{CO}_{3}{ }^{-} \cdot \mathrm{nH}_{2} \mathrm{O}\right]$, optimized to global minima at the $\mathrm{B} 3 \mathrm{LYP} / 6-311++\mathrm{G}(\mathrm{d}, \mathrm{p})$ level of theory, for $\mathrm{n}=1$ to 8 . We chose Maity's $\left[\mathrm{CO}_{3}{ }^{-} .8 \mathrm{H}_{2} \mathrm{O}\right]$ structure as our starting point, replaced the $\mathrm{CO}_{3}{ }^{-}$with the bicarbonate radical, and optimized at CAM-B3LYP/6$31 \mathrm{G}(\mathrm{d}, \mathrm{p})$. Using the same input structure, we successively removed the outermost water molecules to obtain input structures for each smaller cluster. In this way optimized cluster configurations were computed for the set of $\left[\mathrm{HOC}(\mathrm{O}) \mathrm{O}^{\bullet} \cdot \mathrm{nH}_{2} \mathrm{O}\right]$ for $\mathrm{n}=1$ to 8 (see supporting information for examples).

In confirmation that bicarbonate radical is a strong acid we observed that complete ionization was induced by only a few water molecules. The degree of ionization was assessed from the increasing $\mathrm{O}\left(\right.$ acid) $-\mathrm{H}(\mathrm{acid})$ distance $\left(\mathrm{d}_{\mathrm{OH}}\right)$ on increasing values of ' $n$ '. No significant increase in $\mathrm{d}_{\mathrm{OH}}$ was observed for $n=1,2$ or 3 . However $\mathrm{HOC}(\mathrm{O}) \mathrm{O}^{\bullet}$ underwent partial ionization with four water molecules, with $\mathrm{d}_{\mathrm{OH}}$ increasing to $148 \%$ of its unsolvated length. Complete ionization occurred on addition of a fifth water molecule as $\mathrm{d}_{\mathrm{OH}}$ increased to $336 \%$ of its original value. There was then no significant change in bond length for $n>5$. Since the cluster with $n=4$ (structure b in Figure S17 in the SI) appeared to be borderline, we conducted a more extensive search for its alternative minima. While a completely ionized SSIP was found to be very high in energy (isomer $\mathbf{c}$ in Figure S17), structure b rearranged during a Born-Oppenheimer molecular dynamics (BOMD) simulation to a configuration that turned out to be the most stable one upon optimization (structure a in Figure
S17). ${ }^{53}$ This structure, arguably the global minimum, had a "normal", barely elongated $\mathrm{d}_{\mathrm{OH}}$. We concluded that for $\mathrm{HOC}(\mathrm{O}) \mathrm{O}^{\bullet} N_{a q}{ }^{i}=5$ and, from equation (3), this corresponds to a $p K_{a}$ of $\sim-2.4$ (open square in Figure 5). ${ }^{54}$ This result supports the conclusion that $\mathrm{HOC}(\mathrm{O}) \mathrm{O}^{\bullet}$ has a $p K_{a}$ value in the same range as $\mathrm{H}_{2} \mathrm{SO}_{4}$, but probably higher than $\mathrm{HCl}$.

For further quantification of the $p K_{a}$ value of $\mathbf{1}$, free-energy molecular dynamics simulations could be performed in a bulk aqueous environment, but these calculations would be rather expensive at the required level (CAM-B3LYP for an openshell system). Based on our computations we are confident, however, that the $p K_{a}$ value of $\mathbf{1}$ will be around -2 to -1, helping to establish it as the strongest carboxylic acid.

\section{CONCLUSIONS}

We observed pleasing complementarity between spectroscopic investigations of the methyl carbonate radical 7 , as a model for the elusive bicarbonate radical $\mathbf{1}$, and DFT computational studies of the latter. Radical 7 was shown to add very rapidly to aromatic and heterocyclic rings in preference to abstracting $\mathrm{H}$-atoms from benzylic type sites. From radical concentration measurements, the activation energy for decarboxylative decomposition of 7 was found to be $\sim 14 \mathrm{kcal} \mathrm{mol}^{-1}$. It follows that 7 has considerable structural integrity and a half-life of $\sim 0.4 \mathrm{~ms}$ at $300 \mathrm{~K}$ (in the absence of reactive substrates). The preference of 7 for addition over $\mathrm{H}$-abstraction extended to mono-unsaturated lipid components including oleate and cholesterol. However, for lipid components containing 'skipped' (i.e. 1,4-) diene moieties, abstraction of their bisallylic $\mathrm{H}$-atoms took place alongside addition to their double bonds.

By analogy, the neutral bicarbonate radical 1 should actually decarboxylatively decompose more slowly and have a considerably longer half-life than 7. DFT computations reinforced this conclusion. Activation enthalpies for $\beta$-scission of 1 were computed to be $20 \pm 1.0 \mathrm{kcal} \mathrm{mol}^{-1}$ in gas and non-polar media. It follows that, on generation in lipid microstructures, radical 1 will be a significant contributor to peroxidation. Furthermore, this peroxidation probably differs significantly from that by other ROS such as hydroxyl radicals. The latter initiate peroxidation by preferentially abstracting allylic and bis-allylic H-atoms from mono- and poly-unsaturated lipid components. However, because model radical 7 preferentially adds to double bonds, it is probable that $\mathbf{1}$ behaves likewise; particularly with mono-unsaturated lipid components. Important metabolites from peroxidation of cholesterol and oleate by $\mathbf{1}$ are therefore likely to be cholestane-3,5,6-triols and 9,10-dihydroxystearates respectively. Both these types of compounds are known to have a variety of biological activities.

Our DFT computational studies confirmed that $\mathbf{1}$ is a strong acid. $p K_{a} s$ of -0.4 and -0.7 (gas and aqueous phase data respectively) for 1 were obtained from linear correlations of computed deprotonation free energies $\left(\Delta G_{A-H A}\right)$ with the experimental $p K_{a} s$ of a set of strong acids. This may, however, underestimate the true acidity because of neglect of specific solvent interactions. These will be pronounced for the conjugate base 2 with its very high charge density. We discovered an intriguing linear relationship between the $p K_{a} \mathrm{~s}$ of strong acids and the integer numbers of water molecules required to induce ionization. DFT computations with the set of structures $\left[\mathrm{HOC}(\mathrm{O}) \mathrm{O}^{\circ} \cdot \mathrm{nH}_{2} \mathrm{O}\right]$ for $\mathrm{n}=1$ to 8 established that only 5 water molecules were needed to bring about complete ionization of the bicarbonate radical. Comparison of this finding with those for other strong acids gave a predicted $p K_{a}$ of ca. - 
2.4 for $\mathbf{1}$. It is interesting to note that this makes 1 the strongest known carboxylic acid; stronger than $\mathrm{CF}_{3} \mathrm{CO}_{2} \mathrm{H}\left(p K_{a}=-\right.$ $0.25)$ and stronger than the carboxyl radical $\left({ }^{\circ} \mathrm{CO}_{2} \mathrm{H} ; p K_{a}=\right.$ $0.2) .{ }^{55}$ The high acidity of 1 can be attributed to the fact that in the conjugate base $\left(\mathrm{CO}_{3}{ }^{--}\right)$charge and electron density are distributed to three O-centers compared to only two O-centers in the conjugate bases $\left(\mathrm{RCO}_{2}^{-}\right)$of most other carboxylic acids.

\section{EXPERIMENTAL SECTION}

Oximes and oxime carbonates were prepared and purified by the methods described previously. ${ }^{12}$

EPR spectra were obtained at $9.5 \mathrm{GHz}$ employing a spectrometer fitted with a rectangular resonant cavity. Solutions of each oxime carbonate, MAP ( 1 equiv. wt/wt) and substrate in $\mathrm{PhH}$ or tert-butylbenzene were prepared and sonicated if necessary. An aliquot $(0.2 \mathrm{~mL})$ was placed in a $4 \mathrm{~mm}$ o.d. quartz tube and de-aerated by bubbling nitrogen for $15 \mathrm{~min}$. Photolysis in the resonant cavity was by unfiltered light from a $500 \mathrm{~W}$ super pressure mercury arc lamp. EPR signals were digitally filtered and double integrated using the Bruker WinEPR software and radical concentrations were calculated by reference to the double integral of the signal from a known concentration of the stable radical DPPH $\left[1 \times 10^{-3} \mathrm{M}\right.$ in $\mathrm{PhMe}$, run under identical conditions. The majority of EPR spectra were recorded with $2.0 \mathrm{~mW}$ power, $0.8 \mathrm{G}_{\mathrm{pp}}$ modulation intensity and gain of $c a .10^{6}$.

All QM calculations were performed using the Gaussian 09 software package. ${ }^{56}$ The high-quality quantum composite method, Gaussian-4, ${ }^{57}$ was employed for exploratory computations (see Supporting Information). Geometries were fully optimised at the CAM-B3LYP/6-31G(d,p) level. Harmonic vibrational frequencies were computed to characterise the nature of the stationary points (transition states were further characterised through tracing the intrinsic reaction coordinate) and to evaluate thermodynamic corrections to enthalpies and free energies at standard pressure and temperature. Energies were refined at the CAM-B3LYP/6-311+G(2d,p) level for CAM-B3LYP/6-31G(d,p) optimized geometries, denoted CAM-B3LYP/6-311+G(2d,p)//CAM-B3LYP/6-31G(d,p), in selected cases including the effects of a polarisable continuum to model bulk solvation (CPCM variant). ${ }^{58} \mathrm{~A}$ BOMD simulation was performed for $\left[\mathrm{DOC}(\mathrm{O}) \mathrm{O}^{\circ} .4 \mathrm{D}_{2} \mathrm{O}\right]$ at the CAM-B3LYP/6-31G(d,p) level using the ChemShell program $^{59}$ as MD driver. Starting from the minimum b (Figure S17) the system was propagated for 20 ps in the NVT ensemble (Nosé-Hoover chain set to $293 \mathrm{~K}$, timestep $1 \mathrm{fs}$ ); selected structures along the trajectory were subjected to full CAMB3LYP/6-31G(d,p) optimizations and energy calculations.

\section{ASSOCIATED CONTENT}

Supporting Information. General experimental and synthesis section, sample EPR spectra, kinetic EPR data for methyl carbonate dissociation, validation of computational methods, DFT optimized structures and energies, ${ }^{1} \mathrm{H}$ and ${ }^{13} \mathrm{C}$ NMR spectra of novel compounds.

\section{AUTHOR INFORMATION}

\author{
Corresponding Authors \\ *mb105@st-andrews.ac.uk; jcw@st-andrews.ac.uk
}

${ }^{\dagger}$ Institute of Organic Chemistry and Biochemistry, Academy of Sciences of the Czech Republic, Flemingovo nam. 2, 166 10 Prague 6, Czech Republic

\section{ACKNOWLEDGMENT}

We thank EaStCHEM for funding and the EPSRC National Mass Spectrometry Service, Swansea. We are grateful to Luke Crawford and Dr. Herbert Früchtl for help with computing.

\section{REFERENCES}

(1) Waugh, A.; Grant, A. Anatomy and Physiology in Health and Illness, Churchill Livingstone, Edinburgh, $11^{\text {th }} \mathrm{ed}$. 2010.

(2) Medinas, D. B.; Cerchiaro, G.; Trindade, D. F.; Augusto, O. IUBMB Life, 2007, 59, 255-262.

(3) (a) Lymar, S. V.; Hurst, J. K. J. Am. Chem. Soc., 1995, 117, 8867-8868; (b) Bonini, M. G.; Radi, R.; Ferrer-Sueta, G.; Ferreira, A. M. D. C.; Augusto, O. J. Biol. Chem., 1999, 274, 10802-10806.

(4) (a) Hodgson, E. K.; Fridovich, I. Arch. Biochem. Biophys., 1976, 172, 202-205; (b) Bonini, M. G.; Miyamoto, S.; Di Mascio P.; Augusto, O. J. Biol. Chem., 2004, 279, 5183651843.

(5) (a) Goss, S. P. A.; Singh, R. J.; Kalyanaraman, B. J Biol. Chem. 1999, 274, 28233-28239; (b) Liochev, S. I.; Fridovich, I. J. Biol. Chem. 2002, 277, 34674-34678; (c) Ramirez, D. C.; Gomez-Mejiba, S. E.; Corbett, J. T.; Deterding, L. J.; Tomer, K. B.; Mason, R. P. Biochem. J. 2009, 417, 341-353; (d) Liochev, S, I.; Fridovich, I. Free Radical Biol. Med. 2010, 48, 1565-1569.

(6) (a) Chawla, O. P.; Fessenden, R. W. J. Phys. Chem., 1975, 79, 2693-2700; (b) Bisby, R. H.; Johnson, S. A.; Parker, A. W.; Tavender, S. M. J. Chem. Soc. Faraday Trans. 1998, 94, 2069-2072; (c) Czapski, G.; Lymar, S. V.; Schwarz, H. A. J. Phys. Chem. A, 1999, 103, 3447-3450.

(7) Armstrong, D. A.; Waltz, W. L.; Rauk, A. Can. J. Chem. 2006, 84, 1614-1619.

(8) (a) Lapenna, D.; Ciofani, G.; Pierdomenico, S. D.; Giamberardino, M. A.; Cuccurullo, F. FEBS Lett. 2005, 579, 245-250; (b) Radi, R. J. Biol. Chem. 2013, 288, 26464-26472. (c) Lapenna, D.; Ciofani, G.; Cuccurullo, C.; Neri, M.; Giamberardino, M. A.; Cuccurullo, F. Free Radical Res. 2012, 46, 1387-1392.

(9) (a) Khairutdinov, R. F.; Coddington, J. W.; Hurst, J. K Biochemistry, 2000, 39, 14238-14249; (b) Menezes; S. L.; Augusto, O. J. Biol. Chem., 2001, 276, 39879-39884.

(10) (a) Augusto, O.; Bonini, M. G.; Amanso, A. M.; Linares, E.; Santos, C. C. X.; De Menezes, S. L. Free. Rad. Biol. Med., 2002, 32, 841-859; (b) Berlett, B. S.; Chock, P. B.; Yim, M. B.; Stadtman, E. R. Proc. Natl. Acad. Sci. USA, 1990, 87, 389-393.

(11) (a) Edge, D. J.; Kochi, J. K. J. Am. Chem. Soc. 1973, 95, 2635-2643; (b) Chateauneuf, J.; Lusztyk, J.; Maillard, B.; Ingold, K. U. J. Am. Chem. Soc. 1988, 110, 6727-6731.

(12) (a) McBurney, R. T.; Slawin, A. M. Z.; Smart, L. A.; Yu, Y.; Walton, J. C. Chem. Commun. 2011, 47, 7974-7976; (b) McBurney, R. T.; Harper, A. D.; Slawin, A. M. Z.; Walton, J. C. Chem. Sci. 2012, 3, 3436 - 3444; (c) McBurney, R. 
T.; Eisenschmidt, A.; Slawin, A. M. Z.; Walton, J. C. Chem. Sci. 2013, 4, 2028-2035.

(13) Fallis, A. G.; Brinza, I. M. Tetrahedron, 1997, 53, 17543-17594.

(14) Bowman, W. R.; Coloonan, M. O.; Fletcher, A. J.; Stein, T. Org. Biol. Chem. 2005, 1460-1467.

(15) Walton, J. C. Acc. Chem. Res. 2014, 47, 1406-1416.

(16) DaBell, P. Report no. 1, The Bicarbonate Radical in Biology and the Atmosphere, University of St. Andrews, School of Chemistry, St. Andrews, 2014, pp. 7-68.

(17) Symons, M. C. R. J. Am. Chem. Soc., 1969, 91, 5924.

(18) (a) Griller D.; Ingold, K. U. Acc. Chem. Res. 1980, 13, 200-206; (b) Griller, D.; Ingold, K. U. Acc. Chem. Res. 1980, 13, 317-323.

(19) Portela-Cubillo, F.; Alonso-Ruiz, R.; Sampedro, D.; Walton, J. C. J. Phys. Chem. A, 2009, 113, 10005-10012.

(20) (a) Schuh, H.-H.; Fischer, H. Helv. Chim. Acta, 1978, 61, 2130-2164; (b) Schuh, H.-H.; Fischer, H. Int. J. Chem. Kinet. 1976, 8, 341-356.

(21) (a) Maillard, B.; Walton, J. C. J. Chem. Soc., Perkin Trans. 2, 1985, 443-450; (b) Bella, A. F.; Jackson, L. V.; Walton, J. C. J. Chem. Soc., Perkin Trans. 2, 2002, 18391843.

(22) Minozzi, M.; Nanni, D.; Walton, J. C. J. Org. Chem. 2004, 69, 2056-2069 and references cited therein.

(23) Hioe, J.; Zipse, H. Radical Stability - Thermochemical Aspects in Encyclopedia of Radicals in Chemistry, Biology and Materials, ed. Chatgilialoglu, C.; Studer, A., Volume 1, Basic Concepts and Methodologies, Wiley, 2012, available online:

http://onlinelibrary.wiley.com/book/10.1002/9781119953678. rad012 (accessed 14/08/2015).

(24) Esterbauer, H. Am. J. Clin. Nutr. 1993, 57, 779S$786 \mathrm{~S}$.

(25) (a) Porter, N. A. Acc. Chem. Res. 1986, 19, 262-268; (b) Jahn, U.; Galano, J.-M.; Durand, T. Angew. Chem., Int. Ed. 2008, 47, 5894-5955; (c) Niki, E. Free Radical Biol. Med. 2009, 47, 469-484; (d) Gruber, F.; Mayer, H.; Lengauer, B.; Mlitz, V.; Sanders, J. M.; Kadl, A.; Bilban, M.; de Martin, R.; Wagner, O.; Kensler, T. W.; Yamamoto, M.; Leitinger, N.; Tschachler, E. FASEB J. 2010, 24, 39-48.

(26) Yin, H; Xu, L.; Porter, N. A. Chem. Rev. 2011, 111, 5944-5972.

(27) Bascetta, E.; Gunstone, F. D.; Walton, J. C. J. Chem. Soc., Perkin Trans. II, 1984, 401 - 406.

(28) Allyllic radical 17 probably saturates more readily and has narrower line widths than radicals $\mathbf{1 6}$ or $\mathbf{s}^{\bullet}$ therefore spectra were also scanned with low power and a small modulation intensity setting to make sure signals for $\mathbf{1 7}$ were not missed.

(29) Note also that each of 16a and 16a exists, of course, as a mixture of 2 enantiomers.

(30) For reviews of EPR determinations of radical conformations see: (a) Kochi, J. K. Adv. Free Radical Chem., 1975, 5, 189-317; (b) Walton, J. C. in Encyclopedia of Radicals in Chemistry, Biology and Materials, eds. Chatgilialoglu, C.; Studer. A. John Wiley \& Sons Ltd, Chichester, UK, 2012, Vol. 1, ch. 7, pp 147-174.

(31) (a) Bascetta, E.; Gunstone, F. D.; Scrimgeour, C. M.; Walton, J. C. J. Chem. Soc. Chem. Commun, 1982, 110-112; (b) Bascetta, E.; Gunstone, F. D.; Walton, J. C. J. Chem. Soc. Perkin Trans. II, 1983, 603 - 613; (c) Kitaguchi, H.; Ohkubo,
K.; Ogo, S.; Fukuzumi, S. J. Am. Chem. Soc. 2005, 127, 6605-6609.

(32) Smith, L. L. Chem. Phys. Lipids 1987, 44, 87-125.

(33) Sevilla, C.; Becker, D.; Sevilla, M. J. Phys. Chem. 1986, 90, 2963-2968.

(34) Smith, L. L. Cholesterol Autoxidation; Plenum Press: New York, 1981.

(35) (a) Brown, A. J.; Leong, S. L.; Dean, R. T.; Jessup, W. J. Lipid Res. 1997, 38, 1730-1735; (b) Ursini, F.; Maiorino, M.; Gregolin, C. Biochim. Biophys. Acta 1985, 839, 62-70.

(36) (a) Pocker, Y.; Davison, B. L.; Deits, T. L. J. Am. Chem. Soc. 1978, 100, 3564-3567; (b) Reisenauer, H. P.; Wagner, J. P.; Schreiner, P. R. Angew. Chem. Int. Ed. 2014, 53, 11766-11771.

(37) (a) Watabe, T.; Sawahata, T. J. Biol. Chem. 1979, 254, 3854-3860; (b) Watabe, T.; Ozawa, N.; Ishii, H.; Chiba, K.; Hiratsuka, A. Biochem. Biophys. Res. Commun. 1986, 140, 632-637.

(38) (a) Datta, P. K.; Ray, A. K.; Barua, A. K.; Chowdhuri, S. K.; Patra, A. F. J. Nat. Prod. 1990, 53, 1347-1348.; (b) D'Armas, H. T.; Mootoo, B. S.; Reynolds, W. F. J. Nat. Prod. 2000, 63, 1669-1671.

(39) (a) Liu, T.-F.; Lu, X.; Tang, H.; Zhang, M.-M.; Wang, P.; Sun, P.; Liu, Z.-Y.; Wang, Z.-L.; Li, L.; Rui, Y.-C.; Li, T.-J.; Zhang, W. Steroids 2013, 78, 108-114; (b) Tang, L.; Wang, Y.; Leng, T.; Sun, H.; Zhou, Y.; Zhu, W.; Qiu, P.; Zhang, J.; Lu, B.; Yan, M.;Chen, W.; Su, X.; Yin, W.; Huang, Y.; Hu, H.; Yan, G.. Steroids 2015, 98, 166-172.

(40) Yanai, T.; Tew, D. P.; Handy, N. C. Chem. Phys. Lett., 2004, 393, 51-57.

(41) See for example: (a) Bell, R. P. The Proton in Chemistry $2^{\text {nd }}$ edition; Cornell University Press: Ithaca, New York, 1973; (b) Miessler, G. L.; Tarr D. A. Inorganic Chemistry $2^{\text {nd }}$ edition; Prentice Hall: Upper Saddle River, NJ, 1999, p. 164.

(42) Zhang, S.; Baker, J.; Pulay, P. J. Phys. Chem. A, 2010, $114,425-431$ and 432-442.

(43) Gutberlet, A.; Schwaab, G.; Birer, O.; Masia, M.; Kaczmarek, A.; Forbert, H.; Havenith, M.; D. Marx, Science 2009, 324, 1545-1548.

(44) (a) Odde, S.; Mhin, B. J.; Lee, S.; Lee, H. M.; Kim, K. S. J. Chem. Phys. 2004, 120, 9524-9535; (b) Flynn, S. D.; Skvortsov, D.; Morrison, A. M.; Liang, T.; Choi, M. Y.; Douberly, G. E.; Vilesov, A. F. J. Phys. Chem. Lett. 2010, 1, 2233-2238.

(45) Weber, K. H.; Tao, F. M. J. Phys. Chem. A 2001, 105, $1208-1213$

(46) Maity, D. K. J. Phys. Chem. A 2013, 117, 8660-8670.

(47) Scott, J. R.; Wright, J. B. J. Phys. Chem. A 2004, 108, 10578-10585.

(48) Krishnakumar, P.; Maity, D. K. J. Phys. Chem. A 2014, 118, 5443-5453.

(49) Re, S.; Osamura, Y.; Morokuma, K. J. Phys. Chem. A 1999, 103, 3535-3547.

(50) Hermida-Ramon, J. M.; Cabaleiro-Lago, E. M.; Rodriguez-Otero, J. Chem. Phys. 2004, 302, 53-60.

(51) Leopold, K. R. Annu. Rev. Phys. Chem. 2011, 62, 327-349.

(52) Pathak, A. K.; Mukherjee, T.; Maity, D. K. Chem. Phys. Chem. 2008, 9, 2259-2264.

(53) Starting from conformer $\mathbf{b}$, during the first 6 ps the MD simulation mainly sampled similar structures with slightly different orientations of the "dangling" $\mathrm{OH}$ bonds (the 
shortest $\mathrm{d}_{\mathrm{OH}}$ fluctuating between ca. $1.0 \AA$ and $1.8 \AA$, mean value ca. $1.2 \AA$ ); at 6 ps a rearrangement toward structure a occurred, after which the proton stayed firmly bound to the carbonate (mean $\mathrm{d}_{\mathrm{OH}} \approx 1.03 \AA$ ).

(54) It should be noted that our calculations were done at a somewhat different level from the literature data summarized in Figure 5. At our level, however, we also find 4 water molecules required for the dissociation of $\mathrm{HCl}$ (as in references $43,44)$, suggesting that the number of 5 water molecules required for $\mathbf{1}$ should be qualitatively reliable. This conclusion is reinforced by an exploratory computation for $\mathrm{HOC}(\mathrm{O}) \mathrm{O}^{\bullet} .5 \mathrm{H}_{2} \mathrm{O}$ at the $\omega \mathrm{B} 97 \mathrm{X}-\mathrm{D} / 6-31 \mathrm{G}^{* *}$ level (i.e. using the same functional as reference 48 ), where a somewhat different minimum is obtained than with CAM-B3LYP (see Supporting Information), but where ionization has occurred during optimization as well.

(55) Jeevarajan, A. S.; Carmichael, I.; Fessenden, R. W. J. Am. Chem. Soc. 1990, 94, 1372-1376.

(56) Gaussian 09, Revision D.01, Frisch, M. J.; Trucks, G. W.; Schlegel, H. B.; Scuseria, G. E.; Robb, M. A.; Cheeseman, J. R.; Scalmani, G.; Barone, V.; Mennucci, B.; Petersson, G. A.; Nakatsuji, H.; Caricato, M.; Li, X.; Hratchian, H. P.; Izmaylov, A. F.; Bloino, J.; Zheng, G.; Sonnenberg, J. L.; Hada, M.; Ehara, M.; Toyota, K.; Fukuda, R.; Hasegawa, J.; Ishida, M.; Nakajima, T.; Honda, Y.; Kitao, O.; Nakai, H.; Vreven, T.; Montgomery, J. A., Jr.; Peralta, J. E.; Ogliaro, F.; Bearpark, M.; Heyd, J. J.; Brothers, E.; Kudin, K. N.; Staroverov, V. N.; Kobayashi, R.; Normand, J.; Raghavachari, K.; Rendell, A.; Burant, J. C.; Iyengar, S. S.; Tomasi, J.; Cossi, M.; Rega, N.; Millam, J. M.; Klene, M.; Knox, J. E.; Cross, J. B.; Bakken, V.; Adamo, C.; Jaramillo, J.; Gomperts, R.; Stratmann, R. E.; Yazyev, O.; Austin, A. J.; Cammi, R.; Pomelli, C.; Ochterski, J. W.; Martin, R. L.; Morokuma, K.; Zakrzewski, V. G.; Voth, G. A.; Salvador, P.; Dannenberg, J. J.; Dapprich, S.; Daniels, A. D.; Farkas, Ö.; Foresman, J. B.; Ortiz, J. V.; Cioslowski, J.; Fox, D. J. Gaussian, Inc., Wallingford CT, 2009.

(57) Curtiss, L. A.; Redfern, P. C.; Raghavachari, K. J. Chem. Phys., 2007, 126, 84108-84119.

(58) Barone, V.; Cossi, M. J. Phys. Chem. A, 1998, 102, 1995-2001.

(59) a) ChemShell, a Computational Chemistry Shell, see www.chemshell.org; b) Sherwood, P.; de Vries, A. H.; Guest, M. F.; Schreckenbach, G.; Catlow, C. R. A.; French, S. A.; Sokol, A. A.; Bromley, S. T.; Thiel, W.; Turner, A. J.; Billeter, S.; Terstegen, F.; Thiel, S.; Kendrick, J.; Rogers, S. C.; Casci, J.; Watson, M.; King, F.; Kerlson, E.; Sjøvoll, M.; Fahmi, A.; Schäfer A.; Lennartz, C. J. Mol. Struct. (THEOCHEM) 2003, 632, 1-28. 


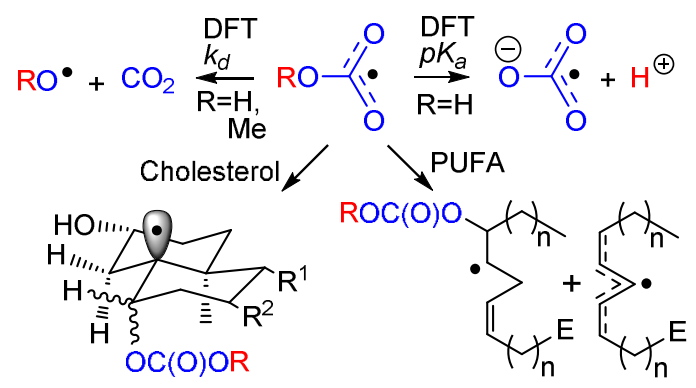

ToC Graphic

13
14
15

15

16

17

18

19

20

21

22

23

24

25

26

27

28

29

30

31

32

33

34

35

36

37

38

39

40

41

42

43

44

45

46

47

48

49

50

51

52

53

54

55

56

57

58

59

60 


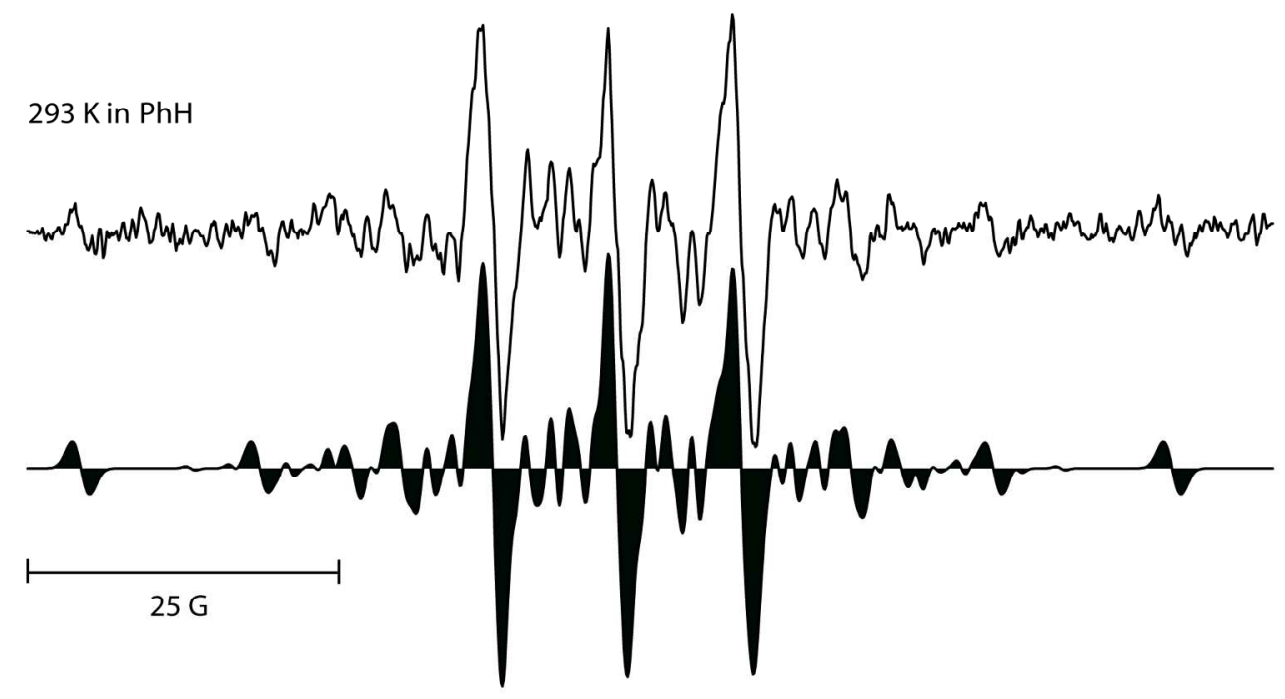

Figure 3. EPR Spectra from $6 \mathrm{~b}$ and Methyl Linoleate 13 $176 \times 99 \mathrm{~mm}(300 \times 300 \mathrm{DPI})$ 


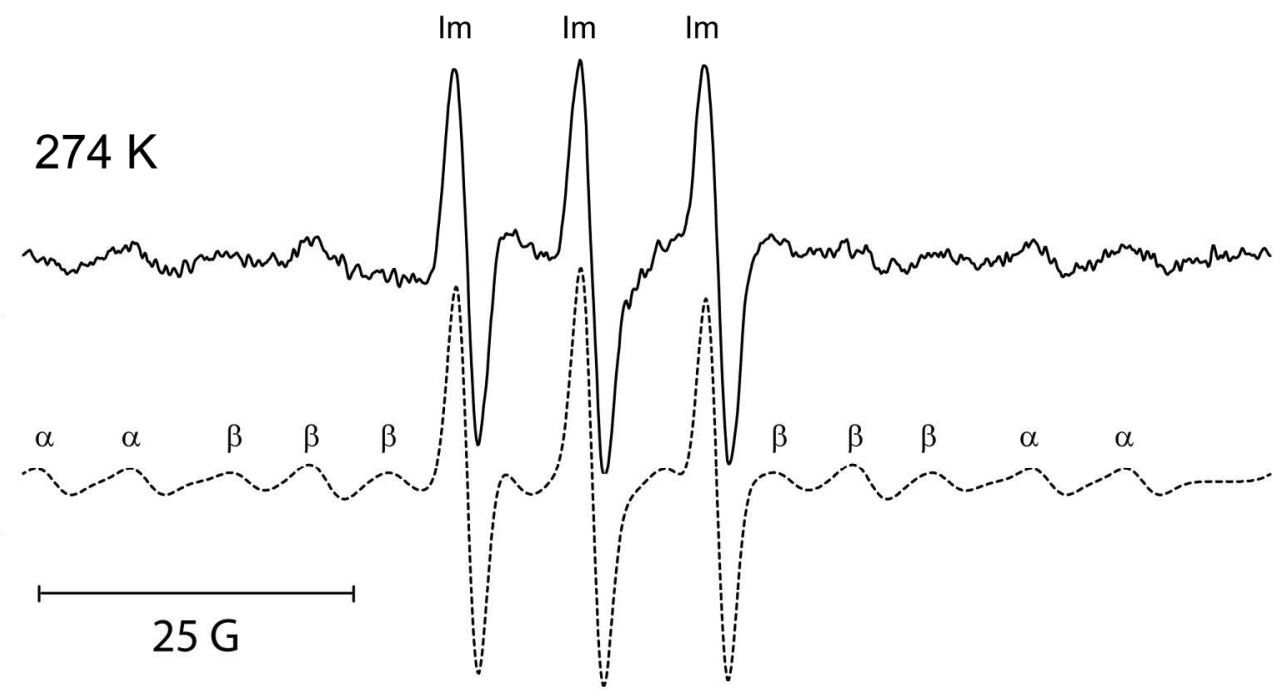

Figure4. EPR Spectra from $6 \mathrm{~b}$ and Cholesterol in PhH at $274 \mathrm{~K}$. $175 \times 98 \mathrm{~mm}(300 \times 300$ DPI $)$ 